\title{
Physical Activity of Urban- Dwelling Older People in Sri Lanka
}

Bimba Wickramarchchi ${ }^{1}$, Sidiah Siop ${ }^{2}$, Bilesha Perera ${ }^{3}$

${ }^{1}$ Department of Nursing, Faculty of Medicine and Health Sciences, Univeriti Malaysia Sarawak, Malaysia; ${ }^{2}$ Department of Nursing, Faculty of Medicine and Health Sciences, Univeriti Malaysia Sarawak, Malaysia; ${ }^{3}$ Departement of Community Medicine, Faculty of Medicine, University of Ruhuna, Sri Lanka

\begin{tabular}{|c|c|c|c|c|c|c|c|c|}
\hline Abstract & Introduction & Methodology & Results & Conclusion & References & Citation & \multicolumn{2}{|c|}{ Tables / Figures } \\
\hline \multicolumn{9}{|c|}{ Corresponding Author } \\
\hline \multicolumn{8}{|c|}{$\begin{array}{l}\text { Name: Bimba Wickramarachchi, 94300, Department of Nursing, Faculty of Medicine and Health } \\
\text { Sciences, Universiti Malaysia Sarawak, Malaysia } \\
\text { E Mail ID: } \underline{\text { bimbawi@gmail.com }}\end{array}$} & 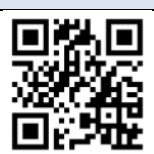 \\
\hline
\end{tabular}

\section{Citation}

Wickramarachchi B, Siop S, Perera B. Physical Activity of Urban- Dwelling Older People in Sri Lanka. Indian J Comm Health. 2020;32(4):717-721. https://doi.org/10.47203/IJCH.2020.v32i04.018

Source of Funding: Nil Conflict of Interest: None declared

\section{Article Cycle}

Received: 13/10/2020; Revision: 24/11/2020; Accepted: 23/12/2020; Published: 31/12/2020 This work is licensed under a Creative Commons Attribution 4.0 International License.

\section{Abstract}

There is a paucity of information on physical activity behaviour of older adults in Sri Lanka. This study determined the physical activity status of urban-dwelling older adults in a district in the country. A cross sectional survey of 880 subjects (aged 60+ years) was conducted using the Global Physical Activity Questionnaire. The prevalence rates of physically inactive, sufficiently active and highly active were $21.5 \%, 78.5 \%$ and $52.7 \%$ respectively. Women were more active than men (Women, $80.9 \%$ versus men, $75.5 \%, p<0.05$ ). Activity at work accounted for the highest portion of physical activity as reported by the participants [Median $=2400 \mathrm{MET} / \mathrm{Week}, 95 \% \mathrm{Cl}: 240,4800$ ] followed by active transport [Median $=120 \mathrm{MET} /$ Week, $95 \% \mathrm{Cl}: 0,560$ ] and leisure-time activity [Median $=0$ MET/Week, 95\% Cl: 0, 270]. Factors contributing for extensively engaging activity at work need further investigations and older adults should be encouraged to do leisure-time physical activities.

\section{Keywords}

Older Adults, Physical Activity, Sri Lanka, Urban-Dwelling

\section{Introduction}

Sri Lanka has one of the fastest ageing populations in Asia.(1) The percentage of older adults over 60 years of age in the country will increase from $12.4 \%$ in 2012 to $29 \%$ in 2050 .(1) Being an agricultural country, older adults in Sri Lanka is largely a physically active cohort. However, socio-cultural changes occurred in the recent past has resulted urbanization of the society and that such transformations have led many older people less active. $(2,3)$ Physical activity is a protective factor for many ageing associated chronic diseases and functional disabilities among older adults. Ranaweera and colleagues (4) reported that $63.4 \%$ of the older adults living in Colombo, a district in Western Sri Lanka were suffering from chronic diseases. Clear understanding of epidemiological underpinnings of physical activity in older adults is vital for promoting health in this group. There is a significant knowledge gap of physical activity behavior in urban-dwelling older adults in Sri Lanka.

\section{Aims \& Objectives}

To identify physical activity status and related sociodemographic factors among urban-dwelling older adults in Sri Lanka.

\section{Material \& Methods}

A cross-sectional community survey was conducted involving a sample of 880 urban-dwelling older people (aged 60 years and over) in Colombo, Sri Lanka. Multi-stage cluster sampling technique was 
used to select participants. The sample was selected based on predefined inclusion and exclusion criteria with participants' informed written consent. Global physical activity questionnaire version 2 (GPAQv2) was employed to assess physical activity status. Data on activity at work, transport and leisure-time related activities were collected and mean metabolic equivalence task per week (MET/week) for each of those activities were calculated. Ethical approval was obtained from Ethics Review Committees of the $X$ and XX. Data analysis was done using SPSS (version 25). Descriptive data was presented by frequency, percentages and median; Interquartile range (IQR) (95\% Cl to the median). Associations of physical activity with socio-demographic variables were determined using Pearson's chi-square test. Significant differences between median of physical activity with the socio-demographic variables were tested by Mann Whitney $U$ test and Kruskal-Wallis test.

\section{Results}

\section{Demographics characteristics}

Mean age of the participants was 70.1 years (SD \pm 6.2). The majority were women (75\%), and about half of the participants (49.7\%) were in the age group 60 - 69 years. About two third of the participants (63.2\%) were in the low-income category (Table1). Prevalence of physical activity

Overall, $78.5 \%$ were sufficiently physically active and $52.7 \%$ were highly active. The intensity of physical activity behaviour declines with increasing age $(p<$ $0.05)$. One fifth of those married were physically inactive. Older adults who were coming from the low-income brackets were more likely to be physically active than others $(p<0.05)$. Older adults who are living with relatives or with non-family members were physically less active than others $(p<$ 0.05) (Table 1).

The median value of the total physical activity was $3360 \mathrm{MET} /$ week (Table 2). Interquartile range of the median of physical activity was $4560 \mathrm{MET} /$ week, indicating a huge variation of physical activity in this group of older adults. Lower levels of participation of vigorous work activity (median; IQR $(95 \% \mathrm{Cl})=0 ; 0$ (0 - 332) and leisure time physical activity (median; IQR $(95 \% \mathrm{Cl})=0 ; 270(0-270)$ were observed. Moderate intensity activity at work is highly prevalent in this sample of older adults. (median value is 2400 $\mathrm{MET}$ /week) which is the main contributor for total activity at work. The study observed almost 'zero' vigorous intensity activity engagement among the participants.

\section{Discussion}

This study investigated physical activity status of urban-dwelling older adults in Sri Lanka. A higher proportion of the participants (79\%) were physically active. Activity at work is the dominant domain of physical activity observed in this target group and leisure time physical activities were highly infrequent in these older adults. The result, however, was in line with studies conducted in other middle-income countries. For example, in Thailand, $74 \%$ of older adults were found to be physically active.(5) However, a systematic review reported that considerable proportion of older adults in many countries around the globe do not engage in recommended levels of physical activity and the figure varies from $40 \%$ to $80 \%$. (6) A study conducted in Sri Lanka on a sample of adults aged 50+ years revealed that $53.0 \%$ and $27.9 \%$ of the participants were engaged in moderate and vigorous physical activities respectively.(4) Therefore, physical activity behaviour of older urban adults in Sri Lanka is commendable.

In general, older men were found to be more physically active than older women,(7) although results of this study found the opposite. Sociocultural and environmental factors may have greatly influenced older women in the country to be more active than men. Even though Sri Lanka is ranking high in gender equality, cultural norms are such that women are confined to do all household chores which make them fully active during the daytime. However, this inclination bars them from doing leisure-time physical activities which are proven to have psychological health benefits at the old-age.

Results of the study indicated that poor older adults were more likely to participate in physical activity at work. Old-age dependency ratio in Sri Lanka is around $18 \%$ presently (8) and a considerable portion of older adults in the country fall below the national poverty line. Thus, financial difficulties may have motivated them to be engaged in work for living. A study done in Vietnam (9) also reported a similar result. About $80 \%$ of physical activities done by older adults in this study were coming from their work related activities. However, in contrast to our findings, a study done in Republic of Serbia reported 
a 'low' level of activity at work,(10) by older adults probably due to socio-economic and cultural differences of these countries.

Participation in leisure time activities is considerably low among older adults in this sample as seen in many other similar studies. For example, only $4 \%$ of older adults in urban China were found to be engaged in leisure time physical activities.(11) In the higher income countries, however, a considerable proportion of older people are engaged in leisure time physical activities.(12) Further, vigorous leisure time activity, an important component of leisure time activity, was found to be almost 'zero' among older adults in the current study. Although active transport behaviour was low among participants in this study, it was the second main physical activity participation of the target group. Urban older adults live in limited land lots and in crowded built environment. This may restrict them engaging in leisure time activities and walking as a habit. It has been suggested that marital status influence the physical activity behaviour.(13)In our study, a higher percentage of singles or those who were separated were found to be 'highly active' than that of others, although a previous study reported the opposite.(13) For singles activity at work is greatly needed to survive. Our observation that economically deprived older people were more likely to be 'sufficiently physically active' support this assertion.

\section{Conclusion}

Physical activity status of urban-dwelling older adults in Sri Lanka is satisfactory. Economic hardships may have contributed to motivate a significant proportion of urban older adults to work for living. Thus, promotion of leisure time physical activities and active transport in urban older adults should be seriously considered in population-based old-age health promotion programmes for their well-being.

\section{Recommendation}

Transforming urban cities into age-friendly and culture sensitive cities where physical activity can become a pleasurable habit of older people, would be a promising strategy to motive older adults to engage in leisure time physical activities and active transport. Gender inequalities of physical activity and socio-economic status of low-income older people should be considered when designing physical activity promotion programmes to them.

\section{Limitation of the study}

Urban-dwelling older adults from a district in Sri Lanka were recruited for the study. However, we cannot expect significant differences of physical activity behavior in urban-dwelling older people in other districts. Minority ethnic groups were not included in the study.

\section{Relevance of the study}

To the best of to our knowledge, this is the first comprehensive study to report the prevalence of physical activity status of urban-dwelling older population in Sri Lanka. Findings are extremely useful for geriatric care professionals to plan evidencebased effective physical activity programs for older adults living in urban areas. In addition to the contributions made to current literature, findings of this study would also have important implications for future gerontological research. Population-based longitudinal studies are required to understand trends of physical activities in different domains among older adults. The findings will also be useful for policymakers and programme developers to design age-friendly supportive environments to promote leisure time physical activity behavior in urban-dwelling older adults in Sri Lanka.

\section{Authors Contribution}

All authors have contributed equally.

\section{Acknowledgement}

We thank all the participants in this study, community leaders, research assistants and administrative staff of District secretariat area, Colombo, Sri Lanka and administrative staff of Univeriti Malaysia Sarawak.

\section{References}

1. Institute of Policy studies in Sri Lanka. Responding to the challenge of an ageing popula tion population [Internet]. Available from: https://thinkasia.org/bitstream/handle/11540/7884/14-Aging-and-Healthin-Sri-Lanka.pdf?sequence $=1$.

2. Katulanda $P$, Jayawardana $R$, Ranasinghe $P$, Rezvi Sheriff $M$, Matthews DR. Physical activity patterns and correlates among adults from a developing country: the Sri Lanka Diabetes and Cardiovascular Study. Public Health Nutr. 2013;16(09):168492. http://dx.doi.org/10.1017/S1368980012003990

3. Perera B, Watt M, Ostbye T, Rajapakse H, Ranabahu S, Maselko J. Perceptions of successful ageing in Sri Lankan older people: A qualitative study. Asian J Gerontol Geriatr. 2015;10(1):22-30. http://dx.doi.org/10.1186/s12877-017-0489-1

4. Bishwajit G, O'Leary DP, Ghosh S, Yaya S, Shangfeng T, Feng Z. Physical inactivity and self-reported depression among middleand older-aged population in South Asia: World health survey. BMC Geriatr. 2017 28;17(1):100. doi: 10.1186/s12877-0170489-1. PMID: 28454520; PMCID: PMC5410033.[PubMed]. 
INDIAN JOURNAL OF COMMUNITY HEALTH / VOL 32 / ISSUE NO 04 / OCT - DEC 2020

5. Koyanagi A, Stubbs B, Smith L, Gardner B, Vancampfort D. Correlates of physical activity among community-dwelling adults aged 50 or over in six low- and middle-income countries. PLoS One. 2017 27;12(10):e0186992. doi: 10.1371/journal.pone.0186992. PMID: 29077744; PMCID: PMC5659773.[PubMed].

6. Sun F, Norman IJ, While AE. Physical activity in older people: a systematic review. BMC Public Health. 2013 6;13:449. doi: 10.1186/1471-2458-13-449. PMID: 23648225; PMCID: PMC3651278.[PubMed]

7. Kaur J, Kaur G, Ho BK, Yao WK, Salleh M, Lim KH. Predictors of physical inactivity among elderly malaysians: recommendations for policy planning. Asia Pac J Public Health. 2015;27(3):314-22. doi: 10.1177/1010539513517257. Epub 2014 Jan 13. PMID: 24425796.[PubMed].

8. Department of Census and Statistics. Labour Force Statistics Quarterly Bulletin. 2013;(60):1-4. Available from: http://www.statistics.gov.lk/samplesurvey/LFS Q4 Bulletin WEB 2018 final.pdf

9. Au TB, Blizzard L, Schmidt M, Pham LH, Magnussen C, Dwyer T. Reliability and validity of the global physical activity questionnaire in Vietnam. J Phys Act Health. 2010;7(3):410-8. doi: 10.1123/jpah.7.3.410. PMID: 20551499.[PubMed]
10 Age- related decrease in physical activity and functional fitness among elderly men and women. Clin Interv Aging. 2013; 8:54956. doi: 10.2147/CIA.S44112. Epub 2013 May 21. Erratum in: Clin Interv Aging. clin interv aging. 2014;9:979. PMID: 23723694; PMCID: PMC3665513.[PubMed]

11. Zhu W, Chi A, Sun Y. Physical activity among older Chinese adults living in urban and rural areas: A review. J Sport Health Sci. 2016;5(3):281-286. doi: 10.1016/j.jshs.2016.07.004. Epub 2016 Jul 11. PMID: 30356525; PMCID: PMC6188614.[PubMed]

12. Mace CJ, Kerse N, Maddison R, Olds T, Jatrana S, Wham C, Kepa M, Rolleston A, Teh R, Broad J. Descriptive Epidemiology of Physical Activity Levels and Patterns in New Zealanders in Advanced Age. J Aging Phys Act. 2016;24(1):61-71. doi: 10.1123/japa.2014-0230. Epub 2015 May 18. PMID: 25985471.[PubMed]

13. Giuli C, Papa R, Mocchegiani E, Marcellini F. Predictors of participation in physical activity for community-dwelling elderly Italians. Arch Gerontol Geriatr. 2012;54(1):50-4. doi: 10.1016/j.archger.2011.02.017. Epub 2011 Mar 31. PMID: 21453978. [PubMed].

\section{Tables}

TABLE 1 PHYSICAL ACTIVITY STATUS OF THE OLDER PEOPLE ACCORDING TO SOCIO-DEMOGRAPHIC CHARACTERISTICS ( $\mathrm{N}=880$ )

\begin{tabular}{|c|c|c|c|c|c|c|}
\hline \multirow[t]{2}{*}{ Variables } & \multirow[t]{2}{*}{ n (\%) } & \multirow[t]{2}{*}{${ }^{1}$ Inactive } & \multirow{2}{*}{$\begin{array}{l}{ }^{2} \text { Sufficiently } \\
\text { active } \\
\text { n (\%) }\end{array}$} & \multicolumn{2}{|c|}{$\begin{array}{l}\text { Sufficiently active } \\
\text { n (\%) }\end{array}$} & \multirow[b]{2}{*}{${ }^{5 p}$} \\
\hline & & & & $\begin{array}{l}{ }^{3} \text { Moderately } \\
\text { active }\end{array}$ & $\begin{array}{l}{ }^{4} \text { Highly } \\
\text { active }\end{array}$ & \\
\hline Total & 880 & $180(21.5)$ & $700(78.5)$ & $240(27.3)$ & $464(52.7)$ & \\
\hline \multicolumn{7}{|l|}{ Age (years) } \\
\hline $60-69$ & $437(49.7)$ & 69 (15.8) & $368(84.2)$ & $88(20.1)$ & $280(64.1)$ & 0.00 \\
\hline $70-79$ & $387(44.0)$ & $88(22.7)$ & $299(77.3)$ & $131(33.9)$ & $168(43.4)$ & \\
\hline 80 and above & $56(6.3)$ & $23(41.1)$ & $33(58.9)$ & $19(33.9)$ & $14(25.0)$ & \\
\hline${ }^{6} p$ & & \multicolumn{2}{|r|}{0.00} & & & \\
\hline \multicolumn{7}{|l|}{ Gender } \\
\hline Male & $220(25.0)$ & $54(24.5)$ & $166(75.5)$ & 79 (35.9) & $87(39.5)$ & 0.00 \\
\hline Female & $660(75.0)$ & $126(19.1)$ & $534(80.9)$ & $159(24.1)$ & $375(56.8)$ & \\
\hline${ }^{6} P$ & & \multicolumn{2}{|r|}{0.08} & & & \\
\hline \multicolumn{7}{|l|}{ Marital status } \\
\hline Married & $544(61.8)$ & $116(21.3)$ & $428(78.7)$ & $145(26.7)$ & $283(52.0)$ & 0.32 \\
\hline Unmarried and other & $10(1.1)$ & $5(50.0)$ & $5(50.0)$ & $2(20.0)$ & $3(30.0)$ & \\
\hline Widow & $320(36.4)$ & $59(18.4)$ & $261(81.6)$ & $89(27.8)$ & $172(53.8)$ & \\
\hline Separated & $6(0.7)$ & $0(0.0)$ & $6(100.0)$ & $2(33.3)$ & $4(66.7)$ & \\
\hline${ }^{6} P$ & & \multicolumn{2}{|r|}{0.25} & & & \\
\hline \multicolumn{7}{|l|}{ Education } \\
\hline Primary education & $116(13.2)$ & $29(25.0)$ & $87(75)$ & 30 (25.9) & $57(49.1)$ & 0.01 \\
\hline Secondary education & $721(81.9)$ & $143(19.8)$ & $578(80.2)$ & $187(25.9)$ & $391(54.2)$ & \\
\hline Tertiary education & $43(4.9)$ & $8(18.6)$ & $35(81.4)$ & $21(48.8)$ & $14(32.6)$ & \\
\hline${ }^{6} P$ & & \multicolumn{2}{|r|}{0.34} & & & \\
\hline \multicolumn{7}{|l|}{ Family income } \\
\hline Low income & $556(63.2)$ & $98(17.6)$ & $458(82.4)$ & $127(22.8)$ & $331(59.6)$ & 0.00 \\
\hline Middle income & $196(22.3)$ & $48(24.5)$ & $148(75.5)$ & $66(33.7)$ & $82(41.8)$ & \\
\hline High income & $128(14.5)$ & $34(26.6)$ & $94(73.4)$ & 45 (35.1) & $49(38.3)$ & \\
\hline${ }^{6} p$ & & \multicolumn{2}{|r|}{0.01} & & & \\
\hline Living arrangement & & & & & & \\
\hline
\end{tabular}


INDIAN JOURNAL OF COMMUNITY HEALTH / VOL 32 / ISSUE NO 04 / OCT - DEC 2020

[Physical Activity of...] | Wickramarachchi B et al

\begin{tabular}{|c|c|c|c|c|c|c|}
\hline Alone & $94(10.7)$ & $20(21.3)$ & 74 (78.7) & $24(25.5)$ & $50(53.2)$ & 0.00 \\
\hline Spouse & $186(21.1)$ & $36(19.4)$ & $150(80.6)$ & $51(27.4)$ & $99(53.2)$ & \\
\hline Spouse and children & $231(26.3)$ & $49(21.2)$ & $182(78.8)$ & $60(26.0)$ & $122(58.2)$ & \\
\hline Children & $341(38.4)$ & $71(20.8)$ & $270(79.2)$ & 95 (27.9) & $175(51.3)$ & \\
\hline Other & $28(3.2)$ & $4(14.3)$ & $24(85.7)$ & $8(28.6)$ & $16(57.1)$ & \\
\hline
\end{tabular}

${ }^{1}$ Inactive, $<600 \mathrm{MET} /$ Weeks of physical activity; ${ }^{2}$ Sufficiently active, $>600 \mathrm{MET} /$ Weeks of physical activity; ${ }^{3}$ Moderatly active, $>600 \mathrm{MET} /$ Weeks - < $3000 \mathrm{MET} /$ Week of physical activity; ${ }^{4} \mathrm{Highly}$ active, $>3000 \mathrm{MET} /$ Week of physical activity; ${ }^{5} p$, Pearson's chi-square tested association between activity status (inactive, moderately active and highly active) and socio-demographic variables.; ${ }^{6} p$, Pearson's chi-square association between activity status

(inactive and sufficiently active) and socio-demogarphic variables)

TABLE 2 MEDIAN MET/WEEK; INTERQUARTILE RANGE AND (95\% CI FOR THE MEDIAN) OF PHYSICAL ACTIVITY OF THE PARTICIPANTS ( $\mathbf{N}=880)$

\begin{tabular}{|c|c|c|c|c|c|c|c|c|}
\hline \multirow{2}{*}{\multicolumn{2}{|c|}{ Variable }} & \multicolumn{7}{|c|}{${ }^{3}$ Median; Interquartile range (95\% CI) } \\
\hline & & ${ }^{4}$ Total & $\begin{array}{l}{ }^{4} \text { Vigorous } \\
\text { intensity } \\
\text { activity at } \\
\text { work }\end{array}$ & $\begin{array}{l}{ }^{4} \text { Moderate } \\
\text { intensity } \\
\text { activity at } \\
\text { work }\end{array}$ & $\begin{array}{l}{ }^{4} \text { Total } \\
\text { activity at } \\
\text { work }\end{array}$ & $\begin{array}{l}{ }^{4} \text { Active } \\
\text { transport }\end{array}$ & $\begin{array}{l}{ }^{4} \text { Moderate } \\
\text { intensity } \\
\text { leisure } \\
\text { time }\end{array}$ & $\begin{array}{l}\text { Sedentary } \\
\text { time } \\
\text { (min/week) }\end{array}$ \\
\hline \multicolumn{2}{|l|}{ Total } & $\begin{array}{l}3360 ; \\
4560 \\
(960- \\
5520)\end{array}$ & $\begin{array}{l}0 ; 0 \\
(0-332)\end{array}$ & $\begin{array}{l}2400 ; 3470 \\
(130-3600)\end{array}$ & $\begin{array}{l}2400 ; \\
4560 \\
(240- \\
4800)\end{array}$ & $\begin{array}{l}120 ; 560 \\
(0-560)\end{array}$ & $\begin{array}{l}0 ; 270 \\
(0-270)\end{array}$ & $\begin{array}{l}3780 ; 2940 \\
(2100- \\
5040)\end{array}$ \\
\hline \multirow[t]{4}{*}{$\begin{array}{l}\text { Age } \\
\text { (years) }\end{array}$} & $60-69$ & $\begin{array}{l}3920 ; \\
4960 \\
(1920- \\
6880)\end{array}$ & $\begin{array}{l}0 ; 0 \\
(0-0)\end{array}$ & $\begin{array}{l}3360 ; 4860 \\
(900-5760)\end{array}$ & $\begin{array}{l}3360 ; 4920 \\
(1320- \\
6240)\end{array}$ & $\begin{array}{l}200 ; 560 \\
(0-560)\end{array}$ & $\begin{array}{l}126 ; 160 \\
(0-160)\end{array}$ & $\begin{array}{l}3360 ; 2100 \\
(2100- \\
4200)\end{array}$ \\
\hline & $70-79$ & $\begin{array}{l}2400 ; \\
3760 \\
(800- \\
4560)\end{array}$ & $\begin{array}{l}0 ; 0 \\
(0-0)\end{array}$ & $\begin{array}{l}1680 ; 3360 \\
(0-3360)\end{array}$ & $\begin{array}{l}1680 ; \\
3360 \\
(0-3360)\end{array}$ & $\begin{array}{l}0 ; 560 \\
(0-560)\end{array}$ & $\begin{array}{l}162 ; 280 \\
(0-280)\end{array}$ & $\begin{array}{l}4200: 2940 \\
(2520- \\
5460)\end{array}$ \\
\hline & 80 and over & $\begin{array}{l}960 ; \\
3090 \\
(0-3090)\end{array}$ & $\begin{array}{l}0 ; 0 \\
(0-0)\end{array}$ & $\begin{array}{l}120 ; 1360 \\
(0-1360)\end{array}$ & $\begin{array}{l}120 ; 1360 \\
(0-1360)\end{array}$ & $\begin{array}{l}0 ; 445 \\
(0-445)\end{array}$ & $\begin{array}{l}0 ; 360 \\
(0-360)\end{array}$ & $\begin{array}{l}4340 ; 2100 \\
(4200- \\
6300)\end{array}$ \\
\hline & ${ }^{2} p$ & 0.00 & 0.01 & 0.00 & 0.00 & 0.01 & 0.20 & 0.00 \\
\hline \multirow[t]{3}{*}{ Gender } & Male & $\begin{array}{l}2160 ; \\
4095 \\
(665- \\
4760)\end{array}$ & $\begin{array}{l}0 ; 0 \\
(0-0)\end{array}$ & $\begin{array}{l}480 ; 2880 \\
(0-2880)\end{array}$ & $\begin{array}{l}560 ; 3360 \\
(0-3360)\end{array}$ & $\begin{array}{l}0 ; 590 \\
(0-590)\end{array}$ & $\begin{array}{l}0 ; 840 \\
(0-840)\end{array}$ & $\begin{array}{l}3955 ; 2275 \\
(2415- \\
4690)\end{array}$ \\
\hline & Female & $\begin{array}{l}3410 ; \\
4590 \\
(1200- \\
5790)\end{array}$ & $\begin{array}{l}0 ; 0 \\
(0-0)\end{array}$ & $\begin{array}{l}2880 ; 4240 \\
(560-4800)\end{array}$ & $\begin{array}{l}3360 ; \\
4480 \\
(560- \\
5040)\end{array}$ & $\begin{array}{l}160 ; 560 \\
(0-560)\end{array}$ & $\begin{array}{l}0 ; 0 \\
(0-0)\end{array}$ & $\begin{array}{l}3780 ; 2940 \\
(2100- \\
5040)\end{array}$ \\
\hline & ${ }^{1} p$ & 0.00 & 0.03 & 0.00 & 0.00 & 0.28 & 0.00 & 0.59 \\
\hline \multirow[t]{3}{*}{$\begin{array}{l}\text { Family } \\
\text { income }\end{array}$} & Low income & $\begin{array}{l}3600 ; \\
5045 \\
(1400- \\
6445)\end{array}$ & $\begin{array}{l}0 ; 0 \\
0-0)\end{array}$ & $\begin{array}{l}3360 ; 4640 \\
(400-5040)\end{array}$ & $\begin{array}{l}3360 ; \\
4560 \\
(480- \\
5040)\end{array}$ & $\begin{array}{l}160 ; 675 \\
(0-675)\end{array}$ & $\begin{array}{l}0 ; 240 \\
(0-240)\end{array}$ & $\begin{array}{l}3360 ; 2100 \\
(2100- \\
4200)\end{array}$ \\
\hline & $\begin{array}{l}\text { Middle and } \\
\text { high income }\end{array}$ & $\begin{array}{l}2340 ; \\
3780 \\
(660- \\
2340)\end{array}$ & $\begin{array}{l}0 ; 0 \\
(0-0)\end{array}$ & $\begin{array}{l}1440 ; 3360 \\
(0-3360)\end{array}$ & $\begin{array}{l}1560 ; \\
3360 \\
(0-3360)\end{array}$ & $\begin{array}{l}70 ; 555 \\
(306- \\
560)\end{array}$ & $\begin{array}{l}0 ; 0 \\
(0-0)\end{array}$ & $\begin{array}{l}4200 ; 2590 \\
(2940- \\
5530)\end{array}$ \\
\hline & ${ }^{1} p$ & 0.00 & 0.14 & 0.00 & 0.00 & 0.97 & & 0.00 \\
\hline
\end{tabular}

